\title{
An Empirical Study on Innovation of College Blended Teaching under Big Data Analysis
}

\author{
Qianqian Xie ${ }^{1}{ }^{1}$ and Sang-Bing Tsai $\mathbb{D}^{2}$ \\ ${ }^{1}$ Zhengzhou University of Industrial Technology, Zhengzhou, Henan 451100, China \\ ${ }^{2}$ Regional Green Economy Development Research Center, School of Business, Wuyi University, Nanping, China \\ Correspondence should be addressed to Qianqian Xie; jqq1234560615@163.com and Sang-Bing Tsai; sangbing@hotmail.com
}

Received 10 July 2021; Revised 2 August 2021; Accepted 9 August 2021; Published 14 August 2021

Academic Editor: Zaoli Yang

Copyright (C) 2021 Qianqian Xie and Sang-Bing Tsai. This is an open access article distributed under the Creative Commons Attribution License, which permits unrestricted use, distribution, and reproduction in any medium, provided the original work is properly cited.

\begin{abstract}
With the advent of the information age, the way people obtain information has changed profoundly. The wave of informationization in higher education has also come with it, and the teaching mode, teaching content, and teaching form are constantly innovated. How to organically integrate information technology into education teaching in order to care for learners' learning experience and promote the cultivation of new talents is an issue that current educational technology researchers need to pay great attention to. This paper first builds a complete blended teaching model of public English for higher education, but its application effect needs to be further examined. This paper is an investigation in the background of the current era to build a blended teaching model. Based on the continuous development of the era, the ideology and application technology of this field will keep upgrading, so the teaching model also needs to be changed and updated according to the characteristics of the development of the era. The investigation of mixed teaching modes is not permanent. The investigation of the mixed teaching mode is not permanent. At present, only a few courses apply the blended teaching mode. On the basis of the continuous updating of teaching concepts and the latest technologies, it is foreseen that the focus of subsequent investigations will be on the individualized development of the blended teaching mode.
\end{abstract}

\section{Introduction}

The information age has arrived, and the way of accessing information has changed. The wave of informatization in higher education has come along with it, and the teaching mode, content, and form of teaching are constantly innovated [1]. How to integrate information technology into education and teaching, in order to focus on the learning experience of learners and promote the cultivation of new talents, is a problem that current educational technology researchers need to pay close attention to [2]. The rapid development of online courses under the guidance of this policy, online courses continue to impact this traditional college classroom, and how to combine online educational resources of online courses, the effective combination of traditional classroom education makes the integration of online and offline education significant. In recent years, as a new teaching mode of online and offline hybrid teaching mode is being gradually promoted in the university classroom [3]. The hybrid teaching model is a teaching model that combines online courses with traditional teaching. The main purpose of hybrid teaching is to optimize the selection and combination of various skills, learning elements, and learning methods. Optimal teaching effectiveness and maximum economic benefits are obtained [4].

However, blended teaching models need to be based on the requirements of different courses. A combination of online and offline education in all aspects of the curriculum can be implemented effectively [5]. Blended teaching is a combination of traditional classroom and online learning, a mixture of structured and unstructured learning, personalized learning and real-time collaboration, theory blending, and resource blending among several other aspects [6]. The various teaching factors are integrated to effectively 
complement each other, while how to effectively integrate online courses and traditional classroom education needs further research [7]. However, the blended education model as a new educational model requires targeted design of teaching resources, teaching aspects, teaching organization, etc. The actual teaching effect is still far from the expected teaching level, building up a student-centered education and teaching model, while the reform of the model has not touched on structural changes, and blended teaching still has some urgent tasks to be solved [8]. With the continuous development of educational technology and information technology, various online learning platforms are emerging, some of which still have some good learning platforms. The development of online teaching abroad is faster than in China and is reflected in a wider range of applications and has developed to a higher level of application and standardization [9]. For example, the virtual university model of schooling relies on online educational technologies for the organization of teaching and the management of students' courses. The web-based curriculum referred to in this study is the teaching and learning activities conducted through the medium of the web.

Therefore, in order to effectively meet students' learning needs and effectively integrate online course resources and traditional classroom teaching, this study aims to construct a hybrid teaching model based on online classroom and study how to use the hybrid teaching model to improve teaching effectiveness and meet students' individual needs. This study will build a hybrid teaching model based on online courses, relying on the concept of hybrid teaching and related theories. This study investigates the current situation of online teaching, analyzes the current situation of online course teaching to find problems, and studies the hybrid teaching mode based on online course for the problems of online course. Combining theory and practice, we design and implement a case study of teaching English in college with an integrated teaching model based on web-based courses and evaluate its effectiveness to provide a reference for the practice of hybrid education teaching based on web-based courses; apply the proposed web-based hybrid teaching model to a specific course in educational practice; and integrate the "University English" course with the web-based blended teaching model case design to verify the learning effectiveness of the web-based blended teaching model in the course practice, to conduct a practical teaching application study of "University English" as an example to promote the reform of hybrid teaching in universities.

\section{Related Work}

Blended learning is a relatively new term in the field of education. The term "blended learning" was first used to integrate elements of recreational and instructional efforts in preschools [10]. Some pedagogical experts have observed and analyzed the blended learning classroom and students' learning status and finally found that students' attitudes toward blended learning are generally both approving and opposing [11]. First, this mode of teaching reflects that students have certain expectations and beliefs about teaching and learning, while some students who oppose this mode are accustomed to a more holistic teacher teaching style and prefer to receive the knowledge delivered by the teacher in a straightforward manner, and they do not have a high degree of recognition of independent learning, and the blended teaching style will make them feel a great sense of uncertainty [12]. On the other hand, there are also some students who highly approve of the blended teaching environment, believing that they can learn more easily, have more flexibility in learning, master knowledge in more diverse ways, arrange their own learning plans based on their own learning rhythm, and give full play to their own initiative [13].

Researchers see blended learning as "the integration of multiple instructional approaches and technologies designed to combine the advantages of online and classroom learning and to maximize student learning autonomy and flexibility". Scholars understand blended learning as "a combination of traditional face-to-face classroom learning and online learning", and its flexible curriculum design allows for classroom learning without time constraints. In addition, some foreign experts in education have studied the definition and meaning of blended learning [14]. The meaning of "blended learning" is changing with the external environment and time, and blended learning mainly covers the following four concepts, namely: combining diverse teaching methods (such as behaviorism, constructivism, cognitivism) to produce optimal learning outcomes through various teaching techniques; combining or blending multiple networked technologies (such as classrooms, collaborative learning, real-time virtual self-paced learning, streaming video, audio, and text) to achieve educational goals; combining instructional technologies with real work tasks to ensure consistency between learning and work; and synergistically combining various instructional technologies (e.g., video and movies) with face-to-face teacher-led education [15].

With the continuous enrichment and development of blended teaching research and practice, people have a deeper and clearer understanding of its connotation, for example, the Sloan Consortium of the United States quantified the office of blended teaching, and considered that the teaching content carried out through online teaching methods reached " $30 \%$ 79\%", and the teaching in this context can be called blended teaching. The Sloan Consortium quantifies blended learning as "30\%-79\%" of the content delivered online. They argue that blended learning combines face-to-face mechanisms with distance mechanisms. The researchers explain blended learning in three ways: the combination of traditional learning and web-based online learning; the combination of media and tools used in online learning environments; and the combination of a range of educational approaches unrelated to the use of technology. They see blended learning as a combination of both traditional learning and web-based online learning. They see blended learning as a concept that is both simple and complex. Simply put, blended learning is the right combination of online learning and classroom instruction [16].

Scholars have begun to define and focus more on blended learning from the perspective of teaching strategies and methods, and on the design of instruction in blended 
learning environments that combine online and face-to-face instruction. Therefore, at this stage, the concept of blended learning focuses on "interaction" and the changes that blended learning environments bring to interaction and the corresponding changes in instructional design. For example, researchers understand blended learning as a model of learning that results in full interaction between students and students, students and teachers, and students and resources. To this end, researchers call blended learning "a fundamental change and redesign of the instructional model" and suggest three characteristics of blended learning: (1) a shift from teacher-centered to student-centered; (2) increased interaction between students and students, students and teachers, students and content, and students and external resources; and (3) the use of assessment mechanism that combines formative and summative assessment.

In analyzing the level of IT adoption and use in industry, the OECD has proposed a framework for e-commerce analysis, including three dimensions of readiness, intensity, and impact. We believe that blended learning, as an ITdriven approach to educational change, can draw on the OECD framework, in which "readiness to use" is expressed in terms of the design and implementation of blended learning. In the implementation level, Graham et al. have proposed a framework for the implementation of blended learning, which includes three key elements: strategy, structure, and support. From the perspective of blended learning design and implementation, the "structure" can include two different levels of structure: the model of blended learning and the theoretical framework. Researchers propose a blended learning process: needs analysis-selection of media-instructional design solutions-learning content development and collaboration [17]. The blended learning model is not singularly fixed; it is constantly enriched and refined over time, and it changes gradually with the application scenarios. Scholars hold different views on blended learning and teaching models, and researchers have proposed attitude-driven, skill-driven, and competency-driven models. Specifically, the attitudedriven model is the coordinated integration of traditional face-to-face teaching and online teaching; the skill-driven model refers to the interaction between learners and teachers based on the corresponding Internet technologies, such as QQ, WeChat, and email; and the competence-driven model refers to the interaction between learners and teachers to explore a certain problem and communicate based on various online media to solve the problems encountered in learning. This is to solve the various problems encountered in learning [18]. Along with the changes of external technology environment and time, foreign scholars have conducted research and discussion on the connotation of blended teaching concept, teaching characteristics, teaching analysis framework, teaching mode, and teaching effect.

\section{Internet of Things and Information Technology Education}

3.1. "Internet+" Hybrid Education. "Internet + education" is a new form of education that combines Internet technology and education with the continuous development of science and technology today [19]. The "Internet+" education emphasizes the use of Internet technology to promote innovation and development in the field of education, based on the increasing integration of the Internet and the field of education, which has a significant impact on the concept of education; teaching mode, teaching methods, and teaching methods; and so on.

Instead of simply playing PPTs in class and using multimedia such as microphones to explain textbooks, teachers make full use of the convenience provided by the Internet, which largely also accelerates the development of "Internet+" teaching reform of public English in higher education. This has largely accelerated the simultaneous development of "Internet+" teaching reform in the following aspects: (1) "Internet + " has broadened teachers' horizons and enriched the knowledge system of senior public English teachers; (2) "Internet+" has given rise to the "Internet + education" concept. "Internet+" has created the demand for innovative changes in "Internet + education"; and (3) "Internet+" has provided all participants of public English teaching with more convenient access to information and the ability to process information. The Internet environment provides students with information resources for independent learning, such as various micro-lessons, videos, blogs, public websites, teaching software; multimedia provides traditional teaching with all kinds of equipment needed for classes, such as projectors, computers, microphones; teachers act as organizers, instructors, helpers, and facilitators in this model, and are no longer the commanders and dominators they used to be; and students then give full play to their subjective initiative and use independent learning strategies to absorb knowledge efficiently.

\subsection{Web Technology and the Realization of Extracurricular} Practice. The Internet is the basis for the successful implementation of "online" teaching in the blended teaching of public English in higher education [20]. At the same time, the teaching resources used in the face-to-face teaching process between teachers and students in "offline" teaching also need to use online resources. Both "online" and "offline" teaching resources and teaching methods are inseparable from the Internet technology, and their effective integration also requires network technical support. Therefore, "Internet+" provides the network technology support for the blended teaching of public English in higher education $[20,21,22]$.

Public English blended teaching adopts the mode of "online + offline", in which excellent courseware can effectively guide students to learn and master the necessary knowledge. On the one hand, the selection of content for public English courseware is inseparable from the Internet tools, and thanks to the background of "Internet+", teachers can search and filter the essence and classic content, such as video, audio, and pictures, and present them through Internet courseware design tools. On the other hand, when designing courseware, teachers can use a variety of opensource tools on the Internet, such as PPT, PS, Mito, and 
Master of Color, as well as some audio and video editing and insertion tools. The online and offline parts of blended teaching require an Internet environment for teacher-student interaction and discussion, and the teaching of public English in higher education requires even more "interactivity" because it is a language subject. The "Internet+" has brought a variety of Internet social software such as Weibo, QQ, and WeChat, and other social interactive software in exclusive fields such as Nailing, Little Card, and Homework. Teachers can use these software platforms to achieve highfrequency interaction in blended teaching of public English in higher education. Therefore, "Internet+" provides network technical support for blended teaching interaction [23-26].

The interactive design of learning contents including content structure design, multimedia presentation design, problem design of teaching contents, and operability design of teaching tasks cannot be done without the support of mobile platform, as shown in Figure 1. The use of mobile platform can greatly expand the classroom space; teachers can communicate with students before and after class through BBS, QQ groups, blogs, and other ways, and keep abreast of students' learning situation and their feedback. The establishment of various online learning platforms, especially resource sharing platforms in universities, has created a harmonious, open, interactive, and exploratory environment for students, enabling them to freely discuss various issues with online students or teachers equally and easily through the Internet and to maintain an active selfactivation state throughout the learning process. As a result, online learning platforms such as mobile APPs and blackboard platforms are beginning to be truly integrated into students' learning and become an integral part of their learning lives along with classroom learning. In short, the arrival of "Internet+" allows students to access online teaching resources, participate in online classroom learning, and engage in targeted independent learning and communication anytime and anywhere through mobile platforms (see Figure 1).

The implementation process of blended teaching involves multiple subjects such as students, teachers, and schools, which actually forms a complex system and brings challenges to the management of blended teaching. As shown in Table 1, the study revealed that in the survey of the factors influencing the effectiveness of blended teaching in public English, 78.6\% of teachers considered students' interest and initiative as the main factors, and $71.5 \%$ of students considered the sense of self-control as the main factor. This shows that students' initiative and interest in blended teaching of public English are crucial. The "Internet+", however, offers a good solution. Through the Internet system management platform, Internet information storage, and other Internet means, it provides network technical support for the management of the blended teaching system, mainly including the teaching assessment system, teaching resource sharing system, and teaching course arrangement system. Through the hybrid teaching mode, teachers can not only teach through the Internet but also prepare lessons, assign and review homework, and answer questions online, and likewise students can interact with teachers offline to answer questions and solve problems. For example, through the online teaching platform, the teacher uploads the materials of the class to the teaching platform, the students can both refresh their knowledge and complete the homework assigned by the teacher online after class time, and the teacher can focus on answering the questions raised by the students. This learning platform strengthens the practical teaching link in college English teaching and enhances students' comprehensive ability of listening, reading, writing, and translating so that students can truly experience the communicative function of language (see Table 1).

There are many problems in traditional public English teaching in higher education, such as single teaching content, slow update, old cases, and single teaching method. Students have few opportunities to practice English, their self-learning ability cannot be effectively trained and improved, and their comprehensive language skills cannot be exercised at all. However, the traditional teaching method also has its advantages, such as the teacher-student communication in the traditional classroom is a very effective way of emotional interaction between teachers and students, and the face-to-face communication, interaction, correction, and reinforcement between teachers and students are more conducive to timely and effective learning strategy training, timely and effective evaluation and feedback, etc. In the "Internet+" environment, the use of Internet tools and methods can effectively solve these problems, provide more rapid access, and promote more convenient and efficient teaching implementation. Teachers can also use various Internet tools to create rich and up-to-date teaching materials, and can use Internet communication tools to enhance interaction with students and enrich the form of teaching activities. It can be said that "Internet+" promotes the combination of online and offline teaching methods of public English in higher education, and the advantages of the two methods complement each other, making the content of blended teaching of public English in higher education richer and promoting the improvement of teaching effect. It is mainly reflected in the following aspects: (1) the teaching tools provided by "Internet+" have accelerated the production of teaching lesson plans and teaching courseware, breaking the traditional blackboard teaching and updating the teaching methods; (2) "Internet+" has made the teachers' teaching methods more colorful and created a variety of teaching methods with the development of information technology, resulting in teaching methods such as catechism and flipped classroom; and (3) "Internet+" breaks the boundaries of time and space, so that teaching is no longer limited to the classroom, allowing learners to start learning at any place and any time, thus promoting teaching communication between teachers and students, which in turn makes it possible to obtain teaching feedback more quickly in order to improve teaching effectiveness.

Self-directed learning is to give full play to students' main role in teaching activities, stimulate students' inner subject consciousness, change the passive way of learning into a flexible and active way of learning, and give students enough freedom in time and space to choose and internalize 


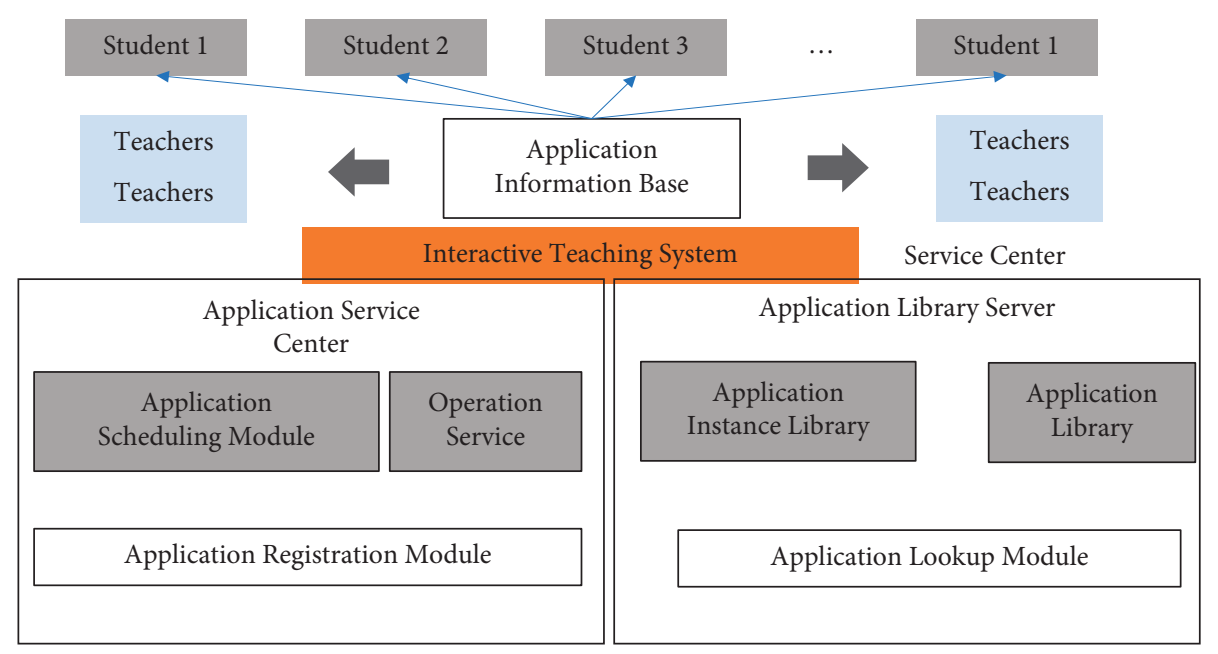

FIGURE 1: Interaction design for mobile platforms.

TABLE 1: Factors influencing the effectiveness of blended teaching of public English.

\begin{tabular}{lclc}
\hline Influencing factors & $\begin{array}{c}\text { Type of } \\
\text { impact }\end{array}$ & Controllability & $\begin{array}{c}\text { Percentage } \\
\text { of }\end{array}$ \\
\hline Interest & $\begin{array}{c}\text { The day } \\
\text { after }\end{array}$ & Controllable & 18.12 \\
Parents & Parents & Controllable & 22.05 \\
Extracurricular & Teachers & Controllable & 45.70 \\
activities & Teachers & Controllable & 45.19 \\
Classroom quality & The day & Controllable & 40.37 \\
Proactivity & after & Uncontrollable & 40.65 \\
Genetic & Parents & Uncontrollable & 40.24 \\
Economic status & Parents & Uncontrollable & 43.43 \\
Parental support & Parents & Uncontrollable & 45.94 \\
Talent & Genes & Uncontrollable & 46.88 \\
Passion & Genes & Uncontrollab \\
\hline
\end{tabular}

the learning content, so that students can really become the master of learning. The main difficulty of English learning for students in higher education institutions is the lack of learning goals and motivation, and the poor learning methods directly lead to low learning efficiency. The lack of basic English knowledge and ability causes their lack of interest and confidence in independent learning and their dependence on teachers. Teachers should analyze different students scientifically and comprehensively, give them targeted guidance, help them improve their basic English knowledge and language ability, and also help them build up confidence and determination in learning, so that they can gradually transition from passive cognition to active cognition and gradually have the ability to learn independently. In the era of "Internet+", teachers can use modern information technology teaching equipment to make courseware or videos of course contents and supplementary knowledge, highlight the key points and difficulties of knowledge, and show them to students through the mobile network platform, while students can use their time after class to study independently by watching courseware and relevant teaching videos and take online test questions to understand their own knowledge of the new language. Students can take self-tests to understand their mastery of new knowledge. Students can also supplement their English knowledge, adjust their learning speed, and conduct repeated learning and tests anytime and anywhere according to their English foundation, so that they can master the teacher's knowledge points before class and reduce their nervousness and shyness in class, and at the same time, increase the interaction between teachers and students in class.

\section{Results and Analysis}

This paper investigates the situation of blended teaching of public English by taking the teachers and students of three provincial colleges as the subjects, with a view to exploring the improvement strategies of blended teaching of public English. The survey was conducted by questionnaires, and the author prepared the "Questionnaire on the Current Situation of Hybrid Teaching of College English (Teachers' Paper)" and "Questionnaire on the Current Situation of Hybrid Teaching of College English (Students' Paper)”. For the survey on the current situation of students, 450 questionnaires were distributed and 400 valid questionnaires were collected, with an effective recovery rate of $88.9 \%$, as shown in Table 2 .

The questionnaire (teachers' paper) was distributed to 27 teachers, and 27 questionnaires were returned, which showed that there were 17 female teachers and 10 male teachers, and the ratio of female teachers to male teachers was $9: 5$. The proportion of teachers aged $20-30$ was $39.3 \%$, and the proportion of teachers over 40 was $21.4 \%$. It is clear that the age distribution of the teachers surveyed is fairly even, but the proportion of young teachers is still relatively high. In addition, $31 \%$ of the teachers were more than 10 years old, 35\% were $6-10$ years old, $28 \%$ were $3-5$ years old, and $6 \%$ were less than 3 years old.

To investigate the value of blended teaching in public English, I designed the survey question "Which of the following aspects do you think is the value of blended teaching in public English?". The majority of teachers chose more 
TABLE 2: Sorting out indicators related to impact factors.

\begin{tabular}{lccc}
\hline Questionnaire type & Number of questionnaires distributed & Number of valid questionnaires & Effective recovery rate (\%) \\
\hline Teachers' paper & 30 & 27 & 90 \\
Students' paper & 450 & 400 & 88.9 \\
\hline
\end{tabular}

than one option. Among them, 71.4\% of teachers chose option A, "optimize teaching structures"; $71.4 \%$ chose option B, "optimize teaching objectives"; $78.6 \%$ chose option C, "optimize teaching idea"; $71.4 \%$ of teachers chose option D, "optimize teachers' personal training and quality"; $82.1 \%$ chose option E, "optimize teaching methods"; $89.3 \%$ of teachers chose option F, "improve the overall quality of students"; and $89.3 \%$ chose option G, "strengthen the adhesion between teachers and students". The following is the distribution chart, as shown in Figure 2.

The results of the above survey show that most teachers believe that the value of blended instruction in public English is manifested in a variety of ways. More than $70 \%$ of teachers chose each of these options. The two most popular choices were "improve the overall quality of students" and "strengthen the adhesion between teachers and students". In addition, when asked about the main purpose of blended teaching in public English, 50\% of the teachers thought that it was to "optimize the teaching system", 50\% thought that it was to "improve students' ability to learn English independently", and no teachers thought that it was to "improve students' ability to learn English independently". No teachers thought that the main purpose of public English blended teaching was to "catch up with the Internet + trend". Figure 3 shows the distribution of the survey results.

The results of the above survey show that there are two different views on the main purpose of public English teaching among higher vocational public English teachers: one believes that the main purpose of public English blended teaching is to "optimize the teaching system" and the other believes that it is to "improve students' ability to learn English independently". With the advent of "Internet+", many models of public English blended teaching have emerged, and some of the more common ones are flipped classroom, micro-lesson, and catechism. In response to the question "Do you know anything about the new educational concepts or models such as 'Internet+' education and blended teaching?", among the 28 teachers who participated in the survey, 26 chose option A, "I often pay attention to it and know a lot about it", accounting for $92.9 \%$; one teacher chose option B, "I have heard of it and know a little about it", accounting for 3.6\%; and one teacher chose option C, "I have heard of it and know a little about it", accounting for 3.6\%. One teacher chose option B, "I have heard of it and know about it", accounting for 3.6\%; one teacher chose option C, "I have heard of it but don't know much about it", accounting for 3.5\%; and no one chose option D, "I don't know much about it". The distribution percentages are shown in Figure 4.

From the above survey results, it can be seen that higher vocational public English teachers generally know a lot about blended teaching and "Internet+" education, and they pay more attention to it. This is also related to the fact that

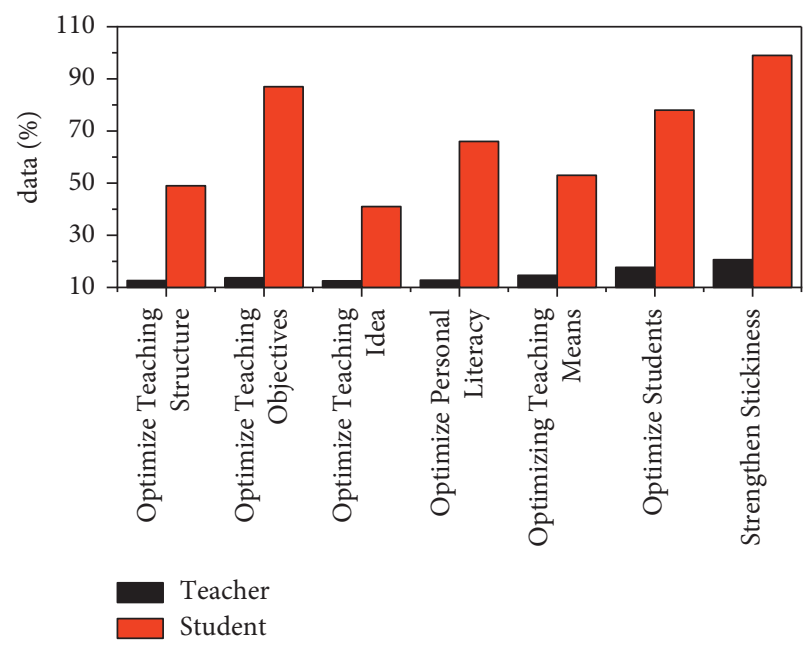

Figure 2: Distribution of blended English teaching roles.

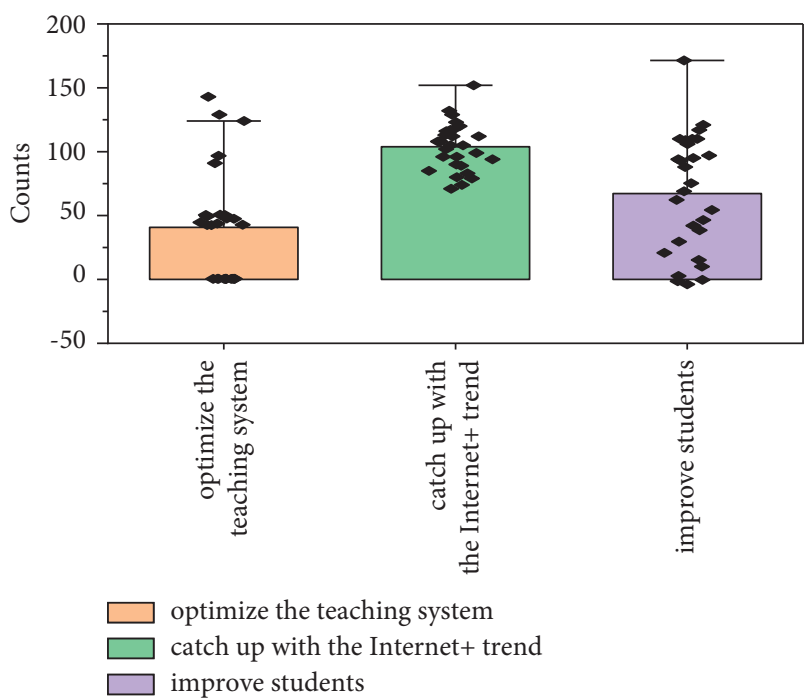

FIgURE 3: Distribution of English blended teaching purpose survey.

public English blended teaching has been implemented in higher education institutions for some time. To further understand teachers' teaching styles, questions 2 and 3 of the questionnaire (teachers' paper) were designed to find out the current teaching styles of public English teachers and their preferred teaching styles, respectively. The results showed that $7.1 \%$ of teachers chose the question "What is the current teaching style of public English?", 7.1\% of teachers chose option A, "teacher-based traditional teaching"; $21.4 \%$ chose option B, "student-based teaching, mainly through online channels"; and $71.5 \%$ chose option C, "combination of traditional lectures and online learning". Figure 5 shows the distribution of the survey results. 


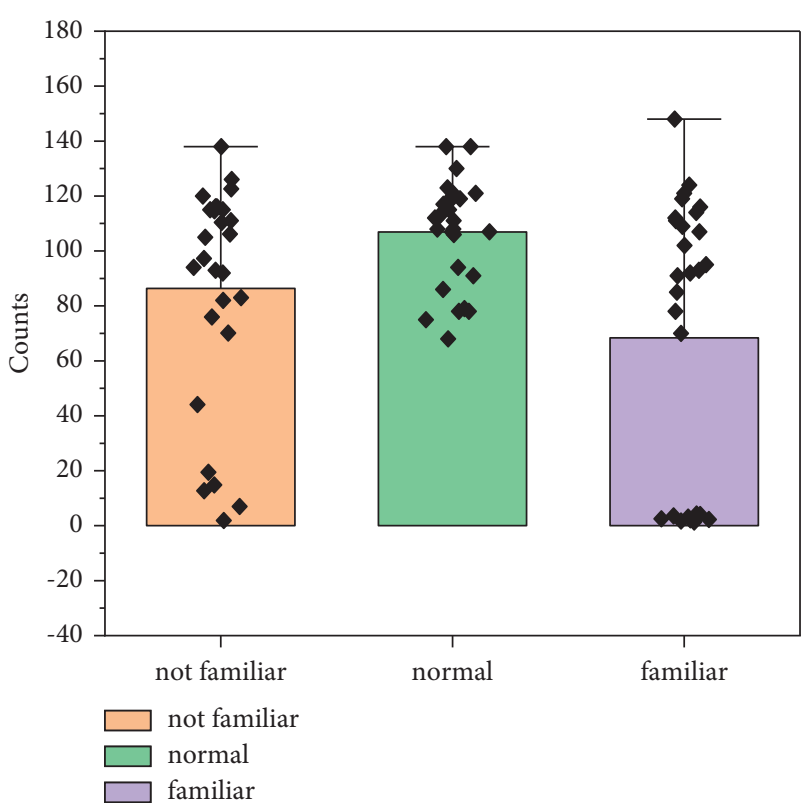

FIGURE 4: Tobit regression results of factors influencing emission reduction efficiency values in the logistics industry.

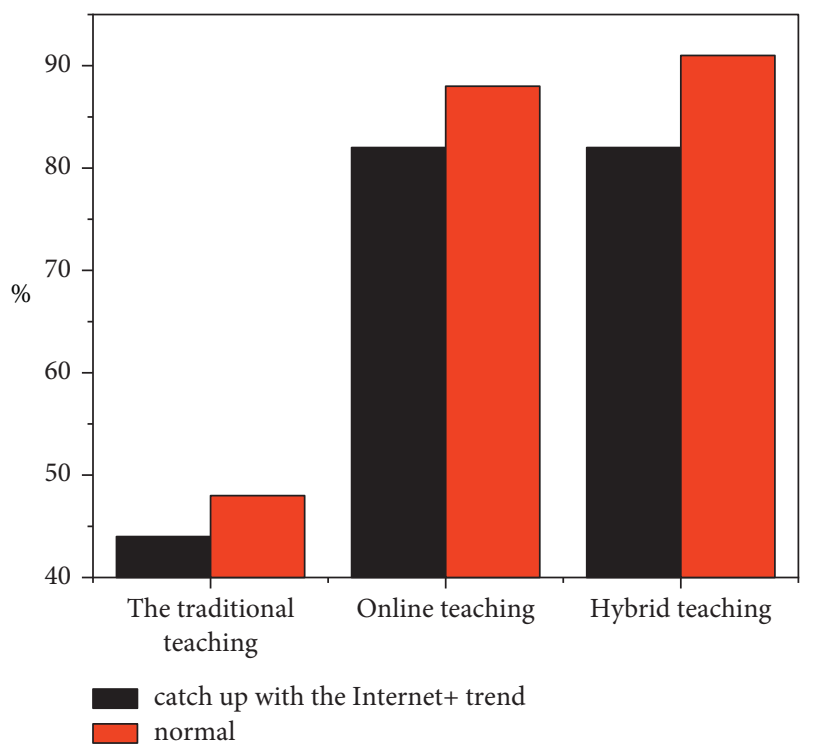

FIGURE 5: Distribution of English blended teaching methods.

In addition, when asked "Which method do you personally prefer in teaching public English?", 39.3\% of teachers chose option A, "face-to-face offline teaching method"; 0 teachers chose option B, "online teaching method without meeting"; and $60.7 \%$ chose option $C$, "integration of online and offline teaching methods". The distribution of the survey is shown in Figure 6. This shows that teachers' initiative and interest in blended teaching of public English are crucial. The "Internet+", however, offers a good solution.

The results of the above survey show that most of the public English teachers in higher education institutions are taking traditional classes and online classes.

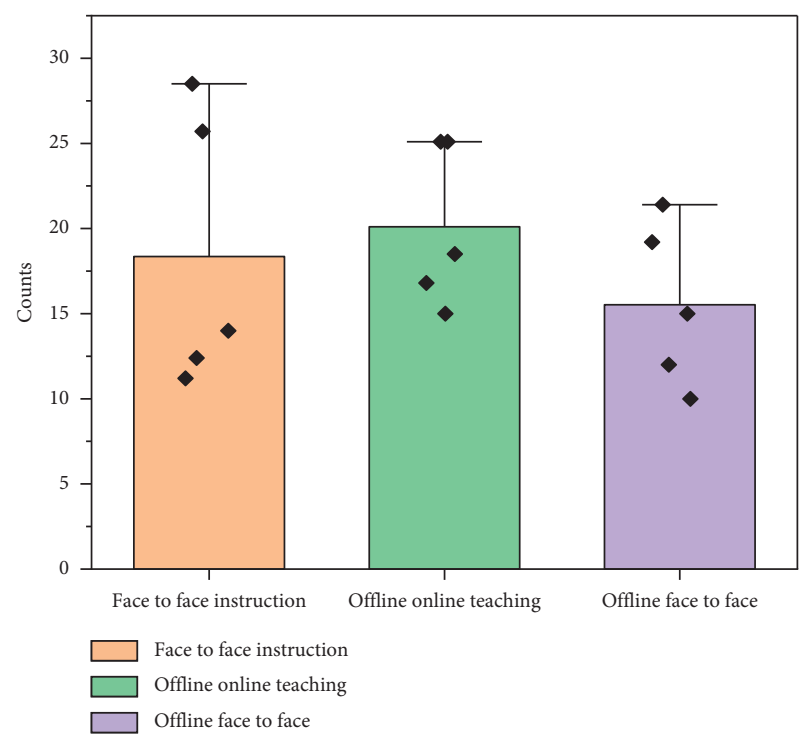

Figure 6: Distribution of teachers' tendency of English blended teaching style.

The percentage of teachers who prefer a combination of online and offline public English instruction is $71.5 \%$ of all teachers surveyed. However, only $60.7 \%$ of teachers prefer a combination of online and offline instruction in terms of teacher preference; $39.3 \%$ of teachers still prefer face-to-face public English teaching. Based on the above perceptions, this paper designed question 4 of the questionnaire (teachers' paper) to investigate the specific methods of public English blended teaching currently adopted by teachers; $82.1 \%$ of the teachers have adopted micro-learning, and $21.4 \%$ of the teachers have adopted other hybrid teaching methods of public English. The effectiveness of public English blended teaching is generally affected by many factors. In response to the question, "Do you think the effectiveness of public English blended instruction is significant?", 39.3\% of the teachers thought that the effectiveness of the current public English blended teaching was obvious; $46.4 \%$ thought that the current public English blended teaching was effective, but not very obvious; and $14.3 \%$ thought that the current public English blended teaching was not effective, as shown in Figure 7. Teachers should analyze different students scientifically and comprehensively, give them targeted guidance, help them improve their basic English knowledge and language ability, and also help them build up confidence and determination in learning, so that they can gradually transition from passive cognition to active cognition and gradually have the ability to learn independently.

The results of the above survey show that since the implementation of the current blended teaching of public English in Province, public English teachers' perceptions of the effects have become obviously different. Most of them think that the current hybrid teaching of public English is effective but not obvious, and a few of them think that it is not effective. To further understand the factors affecting the effectiveness of blended teaching in public English, question 10 of the questionnaire (teachers' paper) investigated the 


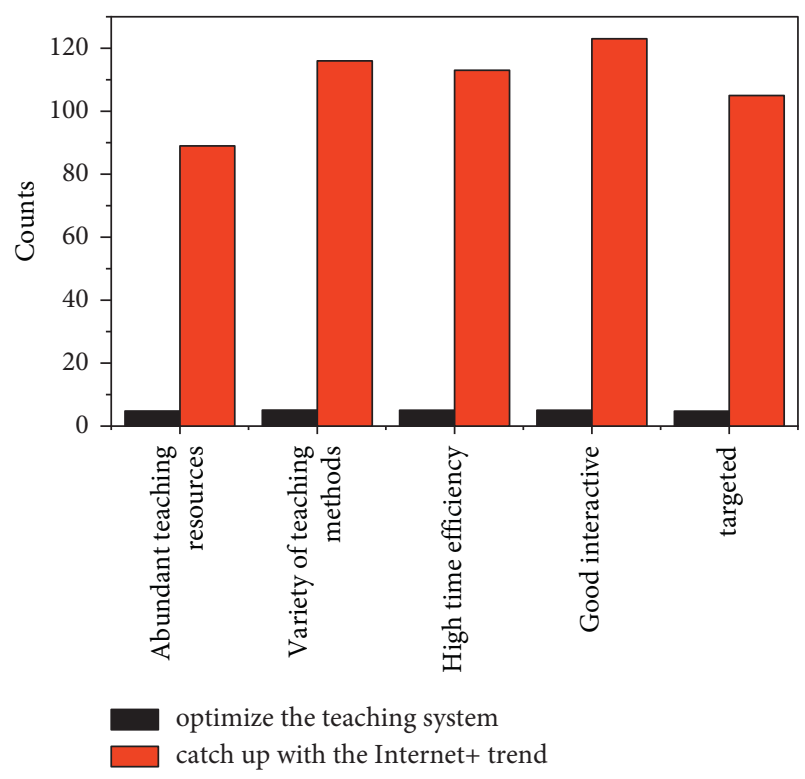

FIgURE 7: Survey on the effectiveness of blended English teaching approach.

factors affecting the effectiveness of blended teaching in public English; $42.9 \%$ of the teachers thought that the school's supporting hardware facilities were the main factor affecting the effectiveness of blended teaching in public English (option A), 39.3\% thought that the quality of courseware was the main factor affecting the effectiveness (option B), 78.6\% thought that students' interest and initiative were the main factors affecting the effectiveness $(C)$, $64.3 \%$ thought that the quality of teachers and teachers' guidance were the main factors affecting the effectiveness (D), $67.9 \%$ of teachers thought that the blended teaching and communication environment was the main factor affecting the effectiveness (E), and $35.7 \%$ of teachers thought that the evaluation system of blended teaching and learning was the main factor affecting the effectivenes (F).

The blended teaching approach of public English has been recognized by many teachers in teaching in higher education institutions across the country and around the world. However, there are some teachers who are not proficient in the operation of using blended teaching and do not have sufficient knowledge of this mode. The first thing that needs to be improved is the teacher training system to realize the systematization of teacher training. Regular participation in training both on and off campus will allow teachers to obtain new information more efficiently and conveniently, better understand new teaching methods and approaches, and further broaden their room for growth. In addition, teachers can focus on improving on-campus and organize some newly joined teachers to jointly observe the exemplary teaching courses, so as to first cultivate some teachers of public English blended teaching and later further expand the scope of cultivation through the driving effect of these teachers, and to first explore a certain aspect of English blended teaching mode and later connect it into a whole and form a system. On the one hand, the observation of exemplary courses allows teachers to learn more intuitively from teaching experience and improve their teaching management. On the other hand, by holding academic discussions and seminars on related topics, teachers can fully participate in off-campus training activities, allowing them to recognize the external environment and improve their knowledge and understanding of blended teaching activities by visiting other schools and exchanging ideas with other teachers. This training mechanism needs to be established with the following aspects in mind: (1) the training mechanism needs to be systematic and planned, so that the training is executed in a planned and targeted manner; (2) whether organizing on-campus training or participating in off-campus training, the design of the training needs to increase interaction and discussion, and introduce excellent cases; and (3) any training effect needs to be fed back and tracked, so as to continuously improve the training program and strategy.

\section{Conclusions}

Blended learning is the optimal "Internet + teaching" learning model, which is also recognized by all sectors of society, including teachers and students. The blended learning model focuses on improving students' modern literacy and competencies, strengthening their international competitiveness and overall quality, and developing them into a new breed of highly qualified human resources. The learning model focuses on strengthening learners' ability to organize and analyze resources and their independent learning ability; the face-toface classroom sessions mainly address learners' ability to overcome difficulties and work in teams; the online and offline interactions between teachers and students mainly cultivate learners' communication and collaboration skills. The research and application of blended teaching mode is still in the initial development period, and the blended teaching with the background of "Internet+" lacks different learning modes combined with subject characteristics and students' knowledge level, and the detailed design of blended teaching needs to be personalized based on students and schools. Therefore, the classroom implementation aspect in the blended teaching model needs to be thought deeply. This paper initially constructs a complete blended teaching model of public English for higher education, but its application effect needs further verification; this paper is an investigation with the current era as the background, so as to build a blended teaching model, and based on the continuous development of the era, the ideology and application technology in this field will continue to upgrade, so the teaching model also needs to be changed and updated with the characteristics of the development of the era. The exploration of blended teaching mode is not permanent. At present, only a few courses have applied the blended teaching mode. Based on the continuous updating of teaching concepts and modern technology, it is foreseeable that the focus of the subsequent investigation will be on the personalized development of the blended teaching mode.

\section{Data Availability}

All the data are included within the paper. 


\section{Conflicts of Interest}

The authors declare no conflicts of interest.

\section{References}

[1] A. B. Heim, E. R. Aldor, and E. A. Holt, "The first line of contact: how course syllabi can be used to gauge \& reform learner- centeredness in a college classroom," The American Biology Teacher, vol. 81, no. 6, pp. 403-409, 2019.

[2] M. M. Chase, E. Bensimon, and J. Robinson, "The implementation of a large-scale pathway reform: how department chairs make sense of and navigate a pathway initiative in a community college," Community College Journal of Research and Practice, vol. 2020, no. 1, pp. 1-18, 2020.

[3] X. Zhang, C. Zang, H. Ma, and Z. Wang, "Study on removing calcium carbonate plug from near wellbore by high-power ultrasonic treatment," Ultrasonics Sonochemistry, vol. 62, Article ID 104515, 2020.

[4] H. Ma, X. Zhang, F. Ju, and S. B. Tsai, "A study on curing kinetics of nano-phase modified epoxy resin," Scientific Reports, vol. 8, no. 1, p. 3045, 2018.

[5] M. Ling, M. J. Esfahani, H. Akbari, and A. Foroughi, "Effects of residence time and heating rate on gasification of petroleum residue," Petroleum Science and Technology, vol. 34, no. 22, pp. 1837-1840, 2016.

[6] K. H. Quartz, M. A. Murillo, B. Trinchero, R. Colina Neri, and S. Jacobo, "Framing, supporting, and tracking college-for-all reform: a local case of public scholarship," The High School Journal, vol. 102, no. 2, pp. 159-182, 2019.

[7] F. Jiang, "The reform of cultivation mode of Chinese university english translation talents in the age of artificial intelligence," Higher Education of Social Science, vol. 18, no. 1, pp. 45-49, 2020.

[8] M. Juelskjær, H. Falkenberg, and V. Larsen, "Students of reforms. investigating and troubling the enactment of student voices in research on reform," International Journal of Qualitative Studies in Education, vol. 31, no. 5, pp. 436-451, 2018.

[9] H. Ma and S. B. Tsai, "Design of research on performance of a new iridium coordination compound for the detection of Hg2+," International Journal of Environmental Research and Public Health, vol. 14, no. 10, p. 1232, 2017.

[10] L. Mo, W. Sun, S. Jiang et al., "Removal of colloidal precipitation plugging with high-power ultrasound," Ultrasonics Sonochemistry, vol. 69, Article ID 105259, 2020.

[11] D. Gao, Y. Liu, Z. Guo et al., "A study on optimization of CBM water drainage by well-test deconvolution in the early development stage," Water, vol. 10, no. 7, 2018.

[12] A. Turnbull and R. Turnbull, "Wrongs, and remedies for inclusive education for students with significant support needs: professional development, research, and policy reform," Research and Practice for Persons with Severe Disabilities, vol. 45, no. 1, pp. 56-62, 2020.

[13] J. S. Rubin, R. M. Good, and M. Fine, "Parental action and neoliberal education reform: crafting a research agenda," Journal of Urban Affairs, vol. 42, no. 4, pp. 492-510, 2020.

[14] D. Xu and H. Ma, "Degradation of rhodamine B in water by ultrasound-assisted $\mathrm{TiO} 2$ photocatalysis," Journal of Cleaner Production, vol. 313, Article ID 127758, 2021.

[15] S. B. Tsai and H. Ma, "A research on preparation and application of the monolithic catalyst with interconnecting pore structure," Scientific Reports, vol. 8, no. 1, 2018.
[16] J. Xie and H. Ma, "Application of improved APO algorithm in vulnerability assessment and reconstruction of microgrid," IOP Conference Series: Earth and Environmental Science, vol. 108, no. 5, Article ID 052109, 2018.

[17] J. A. Birt, M. Khajeloo, C. C. Rega-Brodsky, M. A. Siegel et al., "Fostering agency to overcome barriers in college science teaching: going against the grain to enact reform-based ideas," Science Education, vol. 103, no. 4, pp. 770-798, 2019.

[18] L. Wang, "Research and practice of reform on college english teaching under the environment of information technology," Theory and Practice in Language Studies, vol. 10, no. 4, pp. 453-458, 2020.

[19] H. Chi, "Talents-oriented action on Chinese college english educational reform," Universal Journal of Educational Research, vol. 8, no. 4, pp. 1439-1444, 2020.

[20] S. Zhiyong, G. K. Sidhu, and P. Muthukrishnan, "College english language teaching reform and EFL lecturers' teaching practice: a case study in China," Universal Journal of Educational Research, vol. 8, no. 1, pp. 230-237, 2020.

[21] Z. L. Yang, N. Islam, Y. Shi, K. Venkatachalam, and L. Huang, "The evolution of interindustry technology linkage topics and its analysis framework in 3D printing technology," IEEE Transactions on Engineering Management, vol. 2021, no. 1, pp. 1-15, 2021.

[22] Z. Yang, W. Zhang, F. Yuan, and N. Islam, "Measuring topic network centrality for identifying technology and technological development in online communities," Technological Forecasting and Social Change, vol. 167, Article ID 120673, 2021.

[23] T. Grubljesic, P. S. Coelho, and J. Jaklic, "The shift to socioorganizational drivers of business intelligence and analytics acceptance," Journal of Organizational and End User Computing, vol. 31, no. 2, pp. 37-64, 2019.

[24] L. Z. Zhang, M. Mouritsen, and J. R. Miller, "Role of perceived value in acceptance of "bring your own device policy," Journal of Organizational and End User Computing, vol. 31, no. 2, pp. 65-82, 2019.

[25] A. Shahri, M. Hosseini, K. Phalp, J. Taylor, and R. Ali, "How to engineer gamification: the consensus, the best practice and the grey areas," Journal of Organizational and End User Computing, vol. 31, no. 1, pp. 39-60, 2019.

[26] W. Liu, H. Ma, and A. Walsh, "Advance in photonic crystal solar cells," Renewable and Sustainable Energy Reviews, vol. 116, Article ID 109436, 2019. 